\title{
Lecturers' Perception of Strategies for Enhancing Business Education Research in Tertiary Institutions in Nigeria
}

\author{
James Okoro $^{1}$ \\ ${ }^{1}$ Institute of Education, Delta State University, Abraka, Nigeria \\ Correspondence: James Okoro, Institute of Education, Delta State University, Abraka, Nigeria. E-mail: \\ jimkorokpeu@yahoo.com
}

Received: June 20, 2013

Accepted: July 25, $2013 \quad$ Online Published: November 7, 2013

doi:10.5539/jel.v2n4p102

URL: http://dx.doi.org/10.5539/jel.v2n4p102

\begin{abstract}
Business education programme seems to have been faced with inadequate qualitative research in tertiary institution in Nigeria. The study therefore, assessed the strategies for enhancing Business Education research. Two research questions and six hypotheses guided the study. A 66 item questionnaire was administered to 164 colleges of education and 109 lecturers of universities in South South Nigeria making a total of 273 lecturers. The research questions were answered using mean and while z-test was used to test the null hypotheses. The findings revealed that the inability of students to source current literature, poor knowledge of research procedures by supervisors, poor knowledge of research procedures by students are some of the constraints affecting business education research. The findings also revealed that students' ability to source current literature, knowledge of research procedures by supervisors and knowledge of research procedure by students can enhance business education research. It was recommended that regular workshops and seminars should be organized for lecturers and students on how to supervise and write projects respectively; researchers should ensure that quality information is generated from the study being investigated.
\end{abstract}

Keywords: lecturers' perception, strategies, enhancing, business education research, tertiary institutions, Nigeria

\section{Introduction}

The high rate of young graduates seeking white collar jobs in developing and developed countries has caused unemployment to many citizens. This was a serious concern to the education sectors so that skill acquisition programme was introduced to help to solve this problem. According to the National Policy on Education (FRN, 2009), section 5 sub-section 32, higher education should aim at-

1) The acquisition, development and inculcation of the proper value orientation for the survival of the individuals and society.

2) The development of the intellectual capacities of individuals to understand and appreciate their environments.

3) The acquisition of an objective view of the local and external environments.

In the same vein, section 33 of the policy directs that higher institutions should pursue these goals. Teaching, research, the dissemination of existing and new information, the pursuit of service to the community; and being a store-house of knowledge.

Higher institutions such as the University of Nigeria, Nsukka in 1963 started business education which was an aspect of vocational education programme which is aimed at imparting the necessary skills, attitudes, abilities and relevant knowledge to individuals to enable them to become gainfully employed in order to be self-reliant and reduce unemployment. Akpotowho and Ugeh (2008) opined that Business Education is an aspect of vocational education which has to do with acquisition of practical skills, attitudes, understanding and knowledge and necessary competencies to perform in the world of work. The following courses are taught in Business education at the university level: accounting, management, marketing and distribution, office, technology, information and communication technology, business law and business communication to mention but a few. The role of Business education as recorded in 1999 constitution of the Federal Republic of Nigeria, in section 16(1) - (3) of chapter 11, fundamentally provides for the role of Business education in the economy as follows. 
- It is a tool for harnessing the resources of the nation and promoting national prosperity and an efficient, a dynamic and self-reliant economy;

- It is a tool for controlling the national economy in a manner as to secure maximum welfare, freedom and happiness of social justice and equality of status and opportunity;

- It is a tool for managing and operating the major sectors of the economy, and.

- It is a tool for ensuring that material resources of the nation are harnessed and distributed as best as possible to serve the common good.

Esene (2012) also defined business education as education for and about business or training in business skills and competence required to run businesses successfully without failure. Ekwe (2009) also observed that business education, where it is properly programmed and delivered, can help the recipient to adjust to business environment, and intelligent consumer of goods and services. It can also help to develop an understanding of the nation's economy, establish small-scale business and run it successfully without failure. In order to achieve these laudable goals of business education, there is a need for proper research programme for both lecturers and students.

Research can be simply defined as the search for solutions to problems or answers to questions (Eze, 2010). Similarly, Ndomi (1999) stated that research is concerned with finding facts or testing hypothesis. Furthermore Osuala (2005) opined that research is a process of arriving at dependable solution to problems through the process and systematic collection, analysis and interpretation of data. According to him, research is the most important tool for advancing knowledge for promotion, progress and enabling man to relate more effectively to his environment, to accomplish his purpose, and to resolve conflicts. Therefore, research is a systematic method of trying to find solution to problems or answers to questions. It involves the application of the scientific method in finding solutions to problems. In line with the above definition of research, Eze (2010) defined educational research as a systematic approach to the solution of educational problems. In a similar vein business education research can be defined as a systematic method of trying to find solutions to problems or attempt at finding the explanation for business education problems. Finally, scientifically conducted business education research leads to the production of good results to solve problems that confront Business education programme.

Eze (2010) observed that apart from possessing the above characteristics, research in education in general and business education in particular has a set of sequential steps known as the research process which must be followed when conducting research on any aspect or level of education process

- Identifying and defining the problems

- Reviewing the literature

- Formulating research questions and hypotheses

- Designing the study to collect relevant data

- Collecting relevant data for answering the research questions and testing the hypotheses

- Analyzing the data collected to answer the research questions

- Drawing conclusions/inferences based on the analyses

Research in Business education is to investigate new innovations and technologies in the business world and it can be applied to solve business education problems in order to achieve the stated goal of the programme. It is paramount that teachers and students should embark on intensive research into recent trends in the world of work and applied it to execute business education programmes both in colleges of education and universities. Research in business education ought to search for new skills, inventions and technology to enable the recipient to have knowledge of the business world. Unfortunately, the realization of the tenet of business education through research and publications is vulnerable to some constraints. Eze (2010) identified some constraints on business education research such as

- the inability of students to source current literature,

- poor knowledge of research procedures by supervisors,

- poor knowledge of research procedures by students,

- unwillingness of students to source for current literature,

- poor knowledge of procedures for selecting research topic by students, 
- reproduction/recycling of old projects by students,

- encouragement of students to recycle old projects by lecturers,

- poor knowledge for referencing by students,

- poor knowledge of referencing by supervisors,

- inability of students to define a research problem,

- inability of supervisors to identify bad research questions,

- failure of supervisors to devote time or reading students project,

- inability of students to choose appropriate statistical tools for analysis,

- inability of students to utilize appropriate statistical tools,

- failure of most researches to contribute to knowledge,

- inability of supervisors to identify technical faults in students research work, and

- poor teaching of research methodology.

Okoro (2008) also observed that teachers in Business education and instructional facilities such as typewriters, computers, stop watches, dictating machine, adding machine and guillotine machine are inadequate; this affect teaching and learning. Obuh (2007) observed that many lecturers and students have not developed the skills of using internet services to browse for new information. Ogbomo (2007) also observed that libraries were established to support the educational development of any nation, but presently, libraries are under staffed, data collection is difficult and funding is drastically reduced. Onyemelukwe (2004) observed that time allocated to business education research is too short for proper research.

In the same vein, Umoru (2010) identified the following constraints affecting business education research in Nigeria. These are:

- poor conceptualization of research problems,

- misunderstanding of relevance/usefulness of studies,

- poor clarification of relationships between variables,

- presumptions about validity and reliability of instruments used,

- poor knowledge between common sense and scientific research,

- poor quality information,

- lack of objectivity by the research,

- poor generalization of findings,

- shallow knowledge of procedure in attitude measurement,

- skewed preferences of quantitative over qualitative methods,

- non-availability of congruent and sufficient information,

- poor construction of instruments, difficulty in verification and replication of research reports,

- absence of true experiment studies,

- recommendations not emanating from the findings,

- discrepancy between data collected and tools used for analysis,

- poor grasp of critical methods of data analysis,

- poor interpretation of results,

- poor coding of raw data for analysis,

- problems associated with sampling procedures/techniques,

- poor inductive and deductive reasoning in research.

In the same vein, Jimoh-kadiri (2010) identified the following constraints affecting business education research in Nigeria. Inadequate textbooks, inadequate foreign textbooks, absence of departmental libraries, inadequate foreign journals, inadequate local journals and inadequate libraries stock relevant textbooks, inadequate instructional facilities, inadequate lecturers, inadequate funding and inadequate ICT facilities, facilities are not 
regularly maintained. Jimoh-kadiri (2010) suggested the following strategies for enhancing business education research such as adequate provision of textbooks, adequate provision foreign textbooks, adequate provision relevant textbooks, adequate provision of department libraries, adequate provision of foreign journals, adequate provision of local journals. In the same vein, Umoru (2010) suggested that proper conceptualization of research problems, understanding of useful of studies, clarification of relationships between variables, adequate knowledge between common sense and scientific research, proper quality information and proper generalization of findings and researchers should use relevant tools in gathering data, answering research questions or testing hypotheses. Eze (2010) pointed out the strategies for enhancing business education research such as, students should seek for source of relevant literature, knowledge of research procedure by the supervisor, willingness of student to do proper research and knowledge of procedure for selecting research topics by students.

\subsection{Statement of the Problem}

There is a growing apprehension and fear that the process and types of research in business education in Nigerian tertiary institutions are not only inadequate but generally poor. It is generally believed that the poor quality of research in business education departments of tertiary institutions are caused which most often lead to acrimony between the supervisor and other colleagues. Therefore, the statement of the problem put in question form is what are the strategies for enhancing business education research in tertiary institutions in South South Nigeria?

\subsection{Purpose of the Study}

The purpose of the study was to investigate strategies for enhancing business education research in tertiary institutions in Nigeria. Specifically, the objectives are:

1. To assess the constraints affecting business education research in tertiary institutions in Nigeria.

2. To assess the strategies for enhancing business education research tertiary institutions in Nigeria.

\subsection{Research Questions}

The following research questions guided the study.

- What are the constraints affecting business education research in tertiary institutions in Nigeria?

- What are the strategies for enhancing business education research in tertiary institutions in Nigeria?

\subsection{Hypotheses}

The following hypotheses were tested at 0.05 level of significance:

1. There is no significant difference between male and female lecturers' perception of constraints affecting business education research in tertiary institutions in Nigeria.

2. There is no significant difference between college of education and universities lecturers' perception of constraints affecting business education research in Nigeria.

3. There is no significant difference between less experienced and experienced lecturers of constraints affecting business education research in tertiary institutions in Nigeria.

4. There is no significant difference between male and female lecturers' perception of strategies for enhancing business education research in tertiary institutions in Nigeria.

5. There is no significant difference between college of education and universities lecturers' perception of strategies for enhancing business education research in Nigeria.

6. There is no significant difference between less experienced and experienced lecturers of colleges of education and universities perception of strategies for enhancing business education research in tertiary institutions in Nigeria.

\subsection{Scope of the Study}

This study assessed the constraints affecting Business education research in tertiary institutions in Nigeria. In Nigeria, business education is offered at colleges of education and universities. There are 13 colleges of education and 9 universities offering business education in South South Nigeria.

\section{Methodology}

This was a descriptive survey design which assessed the constraints affecting Business education research at the colleges of education and universities in South South Nigeria. The study consisted of all business education lecturers at the two levels of higher institutions. The sample consisted 164 lecturers of business education at 
college of education and 109 lecturers at Universities, making a total 273. A 66 item questionnaire was the instrument used for the study. It has two sections. Section A has 4 items seeking information on demographic variables while section has 62 items seeking information on research questions. The questionnaire was titled, "Assessment of Strategies for Enhancing Business Education Research Questionnaire". The content and face validity was done by experts in Business Education. The questionnaire was also validated using factors analysis. The test-retest method was used to determine the reliability of the instrument. The questionnaire was first administered to 8 lecturers of Olabisi Onabajo University and 16 lecturers of Ondo State College of Education southwest Nigeria who were not part of the study. After an interval of two weeks, the same questionnaire was administered to the same group of lecturers. The data were analyzed using cronbach alpha which yielded a reliability of coefficient of 0.92 . The instrument was structured on a 4 point type scale of Strongly Agree (SA), Agree (A), Disagree (D) and Strongly Disagreed (SD). In discussing the research question items, if the mean was above 2.5 it was an agreed response, on the other hand, if mean was below 2.5 it was disagreed response. Z-test statistics was used to test the hypothesis at 0.05 level of significance. If the calculated $z$-value (zv) less than $\mathrm{t}$-value (tv), the hypothesis was therefore retrained. If the calculated z-value (zv) greater than table value (tv) the hypothesis was therefore rejected.

\section{Results}

Research Question One: What are the constraints affecting business education research in tertiary institutions in Nigeria?

Table 1. Mean rating of lecturers' perception of constraints affecting business education research in tertiary institutions in Nigeria $(\mathrm{N}=273)$

\begin{tabular}{lllll}
\hline S/N & Items on Constraints affecting Business Education Research & $\mathbf{X}$ & SD & Remark \\
\hline 1 & Inability of students to source for current literature & 2.60 & 0.97 & Agreed \\
2 & Poor knowledge of research procedures by supervisors & 2.76 & 0.81 & Agreed \\
3 & Poor knowledge of research procedures by students & 2.81 & 0.79 & Agreed \\
4 & Unwillingness of students to source for current literature & 2.77 & 0.96 & Agreed \\
5 & Poor knowledge of procedure for selecting research topic by & 2.89 & 1.89 & Agreed \\
& students & 2.82 & 0.96 & Agreed \\
6 & Reproduction/recycling of old projects by students & 2.80 & 0.86 & Agreed \\
7 & Encouragement of students to recycle old projects by lecturers & 2.69 & 0.95 & Agreed \\
8 & Poor knowledge of referencing by students & 2.93 & 0.78 & Agreed \\
9 & Poor knowledge of referencing by supervisors & 2.90 & 0.87 & Agreed \\
10 & Inability of students to define a research problems & 3.00 & 0.78 & Agreed \\
11 & Inability of supervisors to identify bad research questions & 2.90 & 0.86 & Agreed \\
12 & Failure of supervisors to devote time for reading students project \\
13 & Inability of students to utilize appropriate statistical tools & 2.86 & 0.96 & Agreed \\
14 & Inability of students to choose appropriate statistical tools for & 2.83 & 0.79 & Agreed \\
& analysis & & & \\
15 & Failure of most researches to contribute to knowledge & 2.97 & 0.96 & Agreed \\
16 & Inability of supervisors to identify technical faults in students & 2.69 & 0.87 & Agreed \\
& research work & & & \\
17 & Poor teaching of research methodology & 2.79 & 0.95 & Agreed \\
18 & Poor conceptualization research problems & 2.86 & 0.86 & Agreed \\
19 & Misunderstanding of relevance/usefulness of studies & 3.01 & 0.78 & Agreed \\
21 & Poor clarification of relationships between variables & 2.87 & 0.89 & Agreed \\
& Presumptions about validity and reliability of instruments used & 2.80 & 0.86 & Agreed \\
& Poor knowledge between common sense and scientific research & 2.81 & 0.69 & Agreed \\
& & & & \\
& & & &
\end{tabular}




\begin{tabular}{lllll}
23 & Poor quality information & 2.77 & 0.68 & Agreed \\
24 & Lack of objectivity by the researcher & 2.82 & 0.79 & Agreed \\
25 & Poor generalization of findings & 2.87 & 0.59 & Agreed \\
26 & Shallow knowledge of procedure in attitude measurement & 2.94 & 0.94 & Agreed \\
27 & Skewed preferences of quantitative over qualitative methods & 2.90 & 0.67 & Agreed \\
28 & Non-availability of congruent and sufficient information & 2.75 & 0.78 & Agreed \\
29 & Poor construction of instruments & 2.98 & 0.87 & Agreed \\
30 & Difficulty in verification and replication of research reports & 2.65 & 0.95 & Agreed \\
31 & Absence of true experimental studies & 2.98 & 0.97 & Agreed \\
32 & Recommendations not emanating from the findings & 2.69 & 0.97 & Agreed \\
33 & Discrepancy between data collected and tools used for analysis & 2.88 & 0.91 & Agreed \\
34 & Poor grasp of critical methods of data analysis & 2.72 & 0.87 & Agreed \\
35 & Poor interpretation of results & 2.86 & 0.78 & Agreed \\
36 & Poor coding of raw data for analysis & 2.74 & 0.81 & Agreed \\
37 & Problems associated with sampling procedures/techniques & 2.89 & 0.95 & Agreed \\
38 & Poor inductive and deductive reasoning in research & 2.97 & 0.86 & Agreed \\
& Grand mean & $\mathbf{2 . 8 1}$ & $\mathbf{0 . 8 6}$ & Agreed \\
\hline
\end{tabular}

The table above indicated that all the 38 items investigated are constraints facing Business Education Research in Tertiary Institutions in Nigeria with a grand mean of 2.81

Table 2. Mean rating of lecturers perception of strategies for enhancing business education research in tertiary institutions in Nigeria $(\mathrm{N}=273)$

\begin{tabular}{|c|c|c|c|c|}
\hline $\mathbf{S} / \mathbf{N}$ & $\begin{array}{l}\text { Items on STRATEGIES for enhancing Business Education } \\
\text { Research }\end{array}$ & $\mathbf{X}$ & SD & Remark \\
\hline 39 & $\begin{array}{l}\text { Students source for current literature can enhance business } \\
\text { education research }\end{array}$ & 2.82 & 0.92 & Agreed \\
\hline 40 & $\begin{array}{l}\text { Knowledge of research procedures by supervisor can enhance } \\
\text { business education research }\end{array}$ & 2.87 & 0.92 & Agreed \\
\hline 41 & $\begin{array}{l}\text { Knowledge of research procedures by students can enhance } \\
\text { business education research }\end{array}$ & 2.68 & 0.70 & Agreed \\
\hline 42 & $\begin{array}{l}\text { Willingness of students to source for current literature can } \\
\text { enhance business education research }\end{array}$ & 2.90 & 0.90 & Agreed \\
\hline 43 & $\begin{array}{l}\text { Students not recycling old projects can enhance business } \\
\text { education research }\end{array}$ & 3.02 & 0.82 & Agreed \\
\hline 44 & $\begin{array}{l}\text { Proper knowledge of referencing by students can enhance } \\
\text { business education research }\end{array}$ & 2.97 & 0.88 & Agreed \\
\hline \multirow[t]{2}{*}{45} & $\begin{array}{l}\text { Proper knowledge of referencing by supervisor can enhance } \\
\text { business education research }\end{array}$ & 2.86 & 0.98 & Agreed \\
\hline & $\begin{array}{l}\text { Ability of students to define a research problem can enhance } \\
\text { business education research }\end{array}$ & 2.96 & 0.82 & Agreed \\
\hline 46 & $\begin{array}{l}\text { Ability of supervisors to devote time for reading students project } \\
\text { can enhance business education research }\end{array}$ & 2.85 & 0.96 & Agreed \\
\hline 47 & $\begin{array}{l}\text { Ability of supervisor to identify bad research questions can } \\
\text { enhance business education research }\end{array}$ & 2.83 & 0.80 & Agreed \\
\hline
\end{tabular}




\begin{tabular}{|c|c|c|c|}
\hline 48 & $\begin{array}{l}\text { Ability of students to choose appropriate statistical tools for } 2.89 \\
\text { analysis can enhance business education research }\end{array}$ & 0.73 & Agreed \\
\hline 49 & $\begin{array}{l}\text { Ability of students to utilize appropriate statistical tools can } 2.69 \\
\text { enhance business education research }\end{array}$ & 0.79 & Agreed \\
\hline 50 & $\begin{array}{l}\text { Ability of supervisors to identify technical faults in students } 2.75 \\
\text { research work can enhance business education research }\end{array}$ & 0.91 & Agreed \\
\hline 51 & $\begin{array}{l}\text { Adopting research teaching methodology can enhance business } 2.89 \\
\text { education research }\end{array}$ & 0.97 & Agreed \\
\hline 52 & $\begin{array}{l}\text { Good interpretation of results can enhance business education } 2.99 \\
\text { research }\end{array}$ & 0.80 & Agreed \\
\hline 53 & $\begin{array}{l}\text { Grasping of critical methods of data analysis can enhance } 2.89 \\
\text { business education research }\end{array}$ & 0.85 & Agreed \\
\hline 54 & Proper coding of results can enhance business education research & 0.79 & Agreed \\
\hline 55 & $\begin{array}{l}\text { Good construction of research instrument can enhance business } 2.97 \\
\text { education research }\end{array}$ & 0.99 & Agreed \\
\hline 56 & $\begin{array}{l}\text { Knowledge of research procedure in attitude measuring can } 2.89 \\
\text { enhance business education research }\end{array}$ & 0.91 & Agreed \\
\hline 57 & $\begin{array}{l}\text { Proper clarification of relationships between variables can } 2.83 \\
\text { enhance business education research }\end{array}$ & 0.88 & Agreed \\
\hline 58 & $\begin{array}{l}\text { Proper conceptualization research framework can enhance } 2.99 \\
\text { business education research }\end{array}$ & 0.95 & Agreed \\
\hline 59 & $\begin{array}{l}\text { Organizing seminars on research methodology for lecturers can } 2.87 \\
\text { enhance business education research }\end{array}$ & 0.87 & Agreed \\
\hline 60 & $\begin{array}{l}\text { Encouraging lecturers to be more committed to project supervisor } 2.89 \\
\text { can enhance business education research }\end{array}$ & 0.92 & Agreed \\
\hline 61 & $\begin{array}{l}\text { Organizing workshops and brainstorming sessions for lecturers } 2.77 \\
\text { on causes of low can enhance business education research }\end{array}$ & 0.85 & Agreed \\
\hline 62 & $\begin{array}{l}\text { Introduction of research method as a course in business education } 3.00 \\
\text { departments }\end{array}$ & 0.86 & Agreed \\
\hline & Grand mean & 0.82 & Agreed \\
\hline
\end{tabular}

The table above indicated that all the 24 items investigated are strategies for enhancing Business Education Research in Tertiary Institutions in Nigeria with a grand mean of 2.86.

\subsection{Testing of Hypotheses}

The following hypotheses were tested at 0.05 level of significance.

1) There is no significant difference between male and female lecturers' perception of constraints affecting business education research in tertiary institutions in Nigeria.

Table 3. Z-test of male and female lecturers' perception of constraints affecting business education research in tertiary institutions in Nigeria

\begin{tabular}{lllllllll}
\hline Variable categories & $\mathbf{N}$ & $\mathbf{X}$ & SD & Df & Level of sig. & z-cal & z-cal & decision \\
\hline Male lecturers & 161 & 2.58 & 0.86 & & & & & \\
Female lecturers & 112 & 2.41 & 0.80 & 271 & 0.05 & 1.55 & 1.96 & Accepted \\
\hline
\end{tabular}

In the table, the calculated $z$-value of 1.55 is less than the z-tabulated value of 1.96 at 271 degree of freedom and 0.05 level of significance. This means that there was no significant difference between male and female lecturers' perception of constraint affecting business education research. The hypothesis was therefore retained. 
2) There is no significant difference between college of education and universities lecturers' perception of constraints affecting business education research in Nigeria.

Table 4. Z-test of colleges of education and universities lecturers' perception of constraints affecting business education research in Nigeria

\begin{tabular}{lllllllll}
\hline Variable categories & $\mathbf{N}$ & $\mathbf{X}$ & SD & Df & Level of sig. & z-cal & z-cal & decision \\
\hline $\begin{array}{l}\text { College of education } \\
\text { lecturers }\end{array}$ & 164 & 2.72 & 0.90 & & & & & \\
Universities lecturers & 109 & 2.50 & 0.86 & & 0.05 & 1.43 & 1.96 & Accepted \\
\hline
\end{tabular}

In the table, the calculated z-value of 1.43 is less than the $\mathrm{z}$-tabulated value of 1.96 at 271 degree of freedom and 0.05 level of significance. This means that there was no significant difference between colleges of education and universities lecturers' perception of constraints affecting the business education research. The hypothesis was therefore retained.

3) There is no significant difference between less experienced and experienced lecturers perception of constraints affecting business education research in tertiary institutions in Nigeria .

Table 5. Z-test of experienced and less experienced lecturer's perception of constraints affecting business education research in tertiary in Nigeria

\begin{tabular}{lllllllll}
\hline Variable categories & $\mathbf{N}$ & $\mathbf{X}$ & $\mathbf{S D}$ & $\mathbf{D f}$ & Level of sig. & z-cal & z-cal & decision \\
\hline Experienced lecturers & 178 & 2.74 & 0.83 & & & & & \\
Less experienced lecturers & 95 & 2.66 & 0.81 & 271 & 0.05 & 1.26 & 1.96 & Accepted \\
\hline
\end{tabular}

In the table, the calculated z-value of 1.04 is less than the z-tabulated value of 1.96 at 271 degree of freedom and 0.05 level of significance. This means that there was no significant difference between experienced and less experienced lecturers of colleges of education and universities perception of constraint affecting business education research. The hypothesis was therefore retained.

4) There is no significant difference between male and female lecturers' perception of strategies for enhancing business education research in tertiary institutions in Nigeria.

Table 6. Z-test of male and female perception of strategies for enhancing business education research in tertiary intuition in Nigeria

\begin{tabular}{lllllllll}
\hline Variable categories & $\mathbf{N}$ & $\mathbf{X}$ & SD & Df & Level of sig. & z-cal & z-cal & decision \\
\hline Male lecturers & 161 & 2.98 & 0.77 & & & & & \\
Female lecturers & 112 & 2.89 & 0.81 & 271 & 0.05 & 1.32 & 1.96 & Accepted \\
\hline
\end{tabular}

In the table, the calculated z-value of 1.32 is less than the z-tabulated value of 1.96 at 271 degree of freedom and 0.05 level of significance. This means that there was no significant difference between male and female lecturers' perception of strategies affecting business education research. The hypothesis was therefore retained.

5) There is no significant difference between colleges of education and universities lecturers' perception of strategies for enhancing business education research in Nigeria. 
Table 7. Z-test of colleges of education and universities lecturers' perception of strategies for enhancing business education research in Nigeria

\begin{tabular}{lllllllll}
\hline Variable categories & $\mathbf{N}$ & $\mathbf{X}$ & SD & Df & Level of sig. & z-cal & z-cal & decision \\
\hline $\begin{array}{l}\text { Colleges of Education } \\
\text { lecturers }\end{array}$ & 164 & 2.88 & 0.83 & & & & & \\
\begin{tabular}{l} 
Universities lecturers \\
\hline
\end{tabular} & 109 & 2.70 & 0.76 & 271 & 0.05 & 1.18 & 1.96 & Accepted \\
\hline
\end{tabular}

In the table, the calculated z-value of 1.18 is less than the z-tabulated value of 1.96 at 271 degree of freedom and 0.05 level of significance. This means that there is no significant difference between college of education and universities lecturers' perception of strategies for stimulating business education research. The hypothesis was therefore retained.

6) There is no significant difference between less experienced and experienced lecturers of colleges of education and universities perception of strategies for enhancing business education research in tertiary institutions in Nigeria.

Table 8. Z-test of experienced and less experienced lecturers perception of strategies for enhancing business education research in tertiary institutions in Nigeria

\begin{tabular}{lllllllll}
\hline Variable categories & $\mathbf{N}$ & $\mathbf{X}$ & SD & Df & Level of sig. & z-cal & z-cal & Decision \\
\hline Experienced lecturers & 178 & 2.84 & 0.82 & & & & & \\
Less experienced lecturers & 95 & 2.63 & 0.93 & 271 & 0.05 & 1.27 & 1.96 & Accepted \\
\hline
\end{tabular}

In the table, the calculated z-value of 1.27 is less than the z-tabulated value of 1.96 at 271 degree of freedom and 0.05 level of significance. This means that there is no significant difference between experienced and less experienced lecturers of colleges of education and universities perception of strategies for stimulating business education research. The hypothesis was therefore retained.

\section{Discussion of Findings}

The findings revealed that there are constraints affecting business education research in colleges of education and universities in South South Nigeria. These are inability of students to source current literature, poor knowledge of research procedures by supervisors, poor knowledge of research procedures by students, unwillingness of students to source for current literature, poor knowledge of procedures for selecting research topic by students, reproduction/recycling of old projects by students, encouragement of students to recycle old projects by lecturers, poor knowledge for referencing by students, poor knowledge of referencing by supervisors, inability of students to define a research problem, inability of supervisors to identify bad research questions, failure of supervisors to devote time or reading students project, inability of students to choose appropriate statistical tools for analysis, inability of students to utilize appropriate statistical tools, failure of most researches to contribute to knowledge, inability of supervisors to identify technical faults in students research work, poor teaching of research methodology. This study agreed with Eze (2010) and Umoru (2010) who have earlier identified some of these constraints affecting business education research in tertiary institutions in Nigeria. The result of the hypotheses revealed that there was no significant difference between male and female lecturers' perception of constraints affecting business education research in tertiary institutions in Nigeria, there was no significant difference between college of education and universities lecturers' perception of constraints affecting business education research and there was no significant difference between less experienced and experienced lecturers of colleges of education and universities perception of constraint affecting business education research in Nigeria.

The findings also revealed that there are some strategies for enhancing business education research in tertiary institution in Nigeria. These are students should seek for source of relevant literature, knowledge of research procedure by the supervisor, willingness of student to do proper research and knowledge of procedure for selecting research topics by students, ability of supervisor to identify bad research questions, ability of students to choose appropriate statistical tools for analysis, ability of supervisors to identify technical faults in students research work, adopting research teaching methodology, good interpretations of results, grasping of critical 
methods of data analysis, proper coding of results, good construction of research instrument, knowledge of research procedure in attitude measuring, proper clarification of relationships between variables can enhance business education research. This study is in agreement with Eze and Umoru (2010) who earlier identified some of these strategies for enhancing business education research in colleges of education and universities. The result of the hypotheses revealed that there is no significant difference between male and female lecturers' perception of strategies affecting business education research, there is no significant difference between college of education and universities lecturers' perception of strategies for stimulating business education research and there is no significant difference between less experienced and experienced lecturers of colleges of education and universities perception of strategies for stimulating business education research.

\section{Conclusion}

Business education is a tool for entrepreneurial opportunities for business education graduates. The programme has to be adequately funded by the state and federal government through adequate provision of facilities for enhancing qualitative research for lecturers and students in higher institutions.

\section{Recommendations}

The following recommendations are suggested for the study

1) Research method should be made one of the courses in business education departments instead of leaving its teaching schools of education as already practiced in colleges of education.

2) Regular workshops and seminars have to be organized for lecturers and students on how to supervise projects and how to write projects respectively.

3) Researchers should ensure that quality information is generated from the study investigated

4) Relevant information to the study investigated must be obtained

5) Researchers need to be aware of the problems posed by the identified constructs and address them critically

6) Researchers should use relevant tools in gathering data, answering research questions or testing hypothesis.

\section{References}

Akpotowho, F., \& Ughah. (2008). Assessment of the challenges facing NCE business education in Nigeria. Business Education Journal, 6(2), 38-51.

Ekwe, C. (2009). Emerging issues in Business Education and Management Sciences. Delta Business Education Journal, 1(4), 23-28.

Esene, R. A. (2012). Methods of teaching vocational business subjects. Agbor: Royal Pace Publications.

Eze, C. E. (2010). Problems militating against research in business education in selected tertiary institutions in Nigeria. Business Education Journal, 7(2), 55-59.

Federal Government of Nigeria. (2009). National Policy on Education. Lagos: Federal Government Press.

Jimoh-Kadiri, S. O. (2010). Problems of business education research in tertiary institutions. Business Education Research, 7(2), 31-37.

Obuh, A. O. (2007). A survey on the utilization of internet services by undergraduate students of Nigeria universities. A Journal of National Federation of Education trends promoters, 25(8), 66-74.

Ogbomo, E. S. (2007). Impact of library services on educational development in Nigeria Delta. Educational trends. A Journal of the Notional Federation of Education trends Promoters, 25(8), 88-96.

Okoro, J., \& Okoro, P. U. (2005). Adoption joint funding as a strategies for in proving business education standard in Nigeria. Nigerian Journal of research and production, 6(1), 132-140.

Okoro, J. (2008). Assessment of resources for training prospective business education graduates at colleges of education in south south Nigeria. Master Thesis, University of Benin (Unpublished).

Onyemelukwe, R. C. (2004). Assessment of time allocated in business education course. Business Education Journal, 4(2), 88-94.

Umoru, T. A. (2010). Analysis of factors undermining the utilization of research results in business education. Business Education Journal, 7(1), 70-76. 


\section{Copyrights}

Copyright for this article is retained by the author(s), with first publication rights granted to the journal.

This is an open-access article distributed under the terms and conditions of the Creative Commons Attribution license (http://creativecommons.org/licenses/by/3.0/). 